DIANA BLAGA

\title{
THE PHYSIOLOGY OF TASTE. FROM CULINARY TO LITERARY ART
}

By the end of 1935, a society with a rather unusual profile had been created in Bucharest - Divanul meșterilor și cărturarilor de la Hanul Ancuței [The Masters and Scholars' Divan of Ancuța's Inn]. The originality of this group lies in its specific literary-gastronomic character. Also, its relationship with the official bodies of the country is a particular one. The Divan had declared its absolute independence from any form of government. The administration of a restaurant called Ancuța's Inn ensures the finances means for this unconventional society. The restaurant had the additional purpose of accommodating the group's meetings. Furthermore, the profits from the restaurant are also needed to serve as prizes for the young artists of the country. The society is led by Mihail Sadoveanu (as Marele Vornic/ The High Steward) and by Al. O. Teodoreanu (as Marele Logofăt/ The Great Chancellor). Teodoreanu is also the mastermind behind the idea of founding an independent academic society. Of course, the name of this society and of its restaurant has its origins in Sadoveanu's well-known collection of stories.

Both Statutul Divanului [The Divan's Statute] and the adjacent documents that provide information regarding the group (interviews, correspondence) insist on the idea of bringing together in harmony the scholars and artists of the country. The initiators of the society believe that the collaboration and mutual support among Romanian artists are a fundamental component of their relations. This is a reflection of what Giorgio Agamben, following Aristotle, calls "togetherness of thoughts and ideas", a phrase which can be identified as fundamental to humans beings' life as unity ${ }^{1}$. A glimpse of the same atmosphere can also be caught in the literary social soirées that took place here between the world wars. These gatherings counted on the showmanship of the participants and their purpose was not only to put literature on the map, but also to animate the potential public. Usually, these literary social soirées were attended by the most popular writers of those times. They ended up with a banquet, where the cultivated values were friendship and conviviality. The post-performance meal becomes an extension of the stage on which the authors read their writings; it becomes a show in itself ${ }^{2}$.

The gatherings that took place under the aegis of The Masters and Scholars' Divan of Ancuta's Inn were, however, more than an act of communicating with each other. They were first and foremost a way of bringing together the intellectual

\footnotetext{
${ }^{1}$ Giorgio Agamben, "Prietenul" ["The Friend"], in Prietenul și alte eseuri [The Friend and Other Essays]. Translated by Vlad Russo, Bucharest, Humanitas, 2012, p. 20.

${ }^{2}$ Michel Onfray, Rațiunea gurmandă. Filozofia gustului [The Gourmet Mind. The Philosophy of Taste]. Translated by Claudia Dumitriu and Lidia Simion, Bucharest, Nemira, 2000, p. 29.
} 
and artistic elite, with the purpose of forwarding its ideas and values and of ensuring the progress of the country's culture by encouraging and promoting its cultural resources. Al. O. Teodoreanu exposes the intentions of the newly founded society in a letter addressed to N. M. Condiescu, the secretary general of the Royal Foundation Union and the president of The Society of Romanian Writers between 1936 and 1937:

I have high hopes for this society, as it was born out of a joke. [...] the fact that the most representative writers and artists of the country are going to get together around a table twice a year, getting to know each other better and the fact that they are going to offer prizes to the younger ones without any contribution from the government is not a circumstance to neglect. [...] I wish that this society, guided by the love for the Throne and Country, for our language and our traditions, should become a lively and active institution, an impulse and an example to the young, a buffer against the anarchy we see expanding like mange ${ }^{3}$.

Such a perspective is not new to Al. O. Teodoreanu. In line with his mentors from Viața Românească and having exercised his critical judgement with Junimea, he constantly endorsed the values of his native culture, at the same time as he criticised the nationalistic outbursts typical of the supporters of Sămănătorul.

As the society was one of a literary-gastronomic profile, the Divan's steering committee also comprised positions such as Marele Pivnicer (The High Butler) or Marele Paharnic (The High Cupbearer). These titled yeomen were required by the court in former centuries. The rules that highlight the major importance of the gastronomic side of the activities of this academic society can be found in Pravila Hanului [The Inn's Statute Book] and in Hrisovul vel-logofătului [The Chancellor's Charter]. These two documents are both written by the author of Hronicul măscăriciului Vălătuc [The Chronicle of Vălătuc the Jester] in the same style as this collection of stories, which imitates the old chronicles' turn of phrase. Teodoreanu is the one who has also written the menu of the restaurant (Izvodul de mâncări și beuturi cu prețăluiala lor aflatoare la Hanul Ancuței [The Inventory of Meals and Drinks and their Prices at Ancuța's Inn]). A number of the aphoristic, pedagogic annotations in this original menu or in Hrisovul vel-logofătului are also to be found in the gastronomic reviews that Păstorel used to publish in the journals of the day. The meetings of the Divan's members were not supposed to be dull gatherings at all. On the contrary, they were supposed to be well-handled

\footnotetext{
${ }^{3}$ Rodica Pandele (ed.), Păstorel și corespondenții săi [Păstorel and His Correspondents], Bucharest, Eminescu, 1998, p. 80: „Îmi pun mari speranțe în această asociație, pentru că s-a născut din glumă. [...] faptul că cei mai reprezentativi scriitori și artiști ai țării se vor aduna de două ori pe an în jurul unei mese având prilej să se cunoască mai bine și că vor distribui premii celor mai nevrâstnici, fără să ceară ajutorul statului, nu e un amănunt neglijabil. [...] Aș dori ca această societate, în care iubirea de Tron şi Țară, de limba ce-o vorbim şi scriem, de tradițiile acestui neam să fie puncte de reper permanente, să devină o instituție vie și activă, un stimulent și o pildă pentru tineret, o frână pentru anarhia care se întinde ca o lepră". All translations are mine, unless otherwise indicated.
} 
celebrations, where the key ingredients were the banqueters' vivaciousness, their enthusiasm and the Bacchic and gastronomic scenario. Therefore, Marele Paharnic (The High Cupbearer) was in charge of the progression of these celebrations, as he was "responsible for setting the agenda of the Divan's Repasts (banquets)" events took place when the Divan's prizes were awarded ${ }^{5}$ or when a member of the society was celebrated. Such a banquet took place in 1937, when Al. O. Teodoreanu was celebrated for receiving the National Prize for Fiction.

The pivotal role of a meal in the proper proceedings of an artists' society bears a double interpretation. First of all, the explicit intention is noticeable of raising culinary activity to the rank of an art. Secondly, there is a possibility of a more mundane approach: the artist is claiming his humaneness by disclosing and celebrating his mundane inclinations. The differences between artists and the ordinary public are emphasized by the topics of the conversations and the adjacent purposes of these celebratory meals, something that reflects the artists' social status. This reminds us of the writer on vacation as described by Barthes. This writer maintains his status even when he exhibits his humaneness and this only augments the mystification surrounding his remarkableness ${ }^{6}$.

Furthermore, two complementary aspects of a meal can be emphasized: the celebratory one, obvious in the banquet-like events, and the meal as a bonding agent. The latter aspect occurs at the same time as civilisation progresses and is unanimously recorded in studies such as Brillat-Savarin's The Physiology of Taste, in the memoirs of the members of the old manorial families (see Radu Rosetti or Rudolf Suţu; likewise, nowadays, Al. Paleologu), but also in literature, not only as a component of literary history (mostly in the guise of anecdotes), but also as fiction, as illustrated by the stories of Mihail Sadoveanu. The meal as entertainment transcends the primary purpose of satisfying one's hunger and becomes a means of establishing both interpersonal and intrapersonal connections. Here lies the difference between eating for survival and eating as a complex process in which the celebratory aspect prevails. It is the difference between nourishment and gastronomy. It is the path from nature to culture. This ascendancy unveils a civilizing process and circumscribes "human history understood as continuous ascent above nature" . Nietzsche and Foucault emphasized the customised nature of nourishment in the case of every individual. The former thinks that man is predestined to adjust to a certain diet and that, if he keeps to it, he can ensure a

${ }^{4}$ Niculae Gheran, "Divanul meșterilor și cărturarilor de la Hanul Ancuței" ["The Masters and Scholars' Divan at Ancuța's Inn”], Adevărul literar și artistic, 2003, 665, p. 13: "are însărcinarea rânduirei la Praznicele (banchetele) Divanului".

5 Among those who were awarded this prize may be mentioned George Lesnea, Cicerone Theodorescu and the sculptor Ion Irimescu.

${ }^{6}$ Roland Barthes, Mitologii [Mythologies]. Translated by Maria Carpov, Bucharest, Nemira, 2015, pp. 38-39.

${ }^{7}$ Michel Onfray, Rațiunea gurmandă, p. 30. 
harmonious way of life and thinking 8 . Foucault, on the other hand, has a different view on the dietary habit: he considers it a personal alternative, but with the same purpose: that of conditioning the human behaviour and man's access to knowledge - not only about the universe, but also his self-knowledge ${ }^{9}$. In both cases one has in mind a process based on knowledge through senses. Popularisation of such ideas ensured that gastronomy would no longer be perceived as an inferior topic, but as a form of art.

It is no wonder that Mihail Sadoveanu and Al. O. Teodoreanu are the ones to preside over a literary-gastronomic society ${ }^{10}$, as both their literary work and their everyday life incline towards gastronomy in its superior form. However, these two are not pioneers in Romanian literature when it comes to the relation between literature and gastronomy, either fictional or biographical in form. Mihail Kogălniceanu and C. Negruzzi are the first authors of a foreign-inspired cookery book published on Romanian soil: Carte de bucate boierești. 200 de rețete cercate de bucate, prăjituri și alte trebi gospodărești [Manorial Cookery Book. 200 Tested Recipes of Dishes, Sweet Bakes and Other Household Duties] (1841).

Researchers show that in the times of Richard II (the $14^{\text {th }}$ century) arts and culture were at the apogee of prosperity, as this king was the first who showed any interest in these fields. Not incidentally, the first cookery book in England was written at his request. Therefore, cookery books are representative for the evolution of society and by extension for the civilizing process. They also certify the connection between gastronomy and artists (or, generally speaking, intellectuals), who are fundamental mediators in this process. On Romanian soil, Kogălniceanu and Negruzzi are followed by other writers. The most popular example is Păstorel Teodoreanu. His interest in gastronomy is a major one. Although his gastronomic reviews were not published in a book in his lifetime, they are a warranty for his popularity and his legitimacy as a gastronomic reviewer between the two world wars. It is also important to mention both Mihail Sevastos' Carte de bucate $[\text { Cookery Book }]^{11}$ and Constantin Bacalbașa's Dictatura gastronomică. 1501 feluri

\footnotetext{
${ }^{8}$ Friedrich Nietzsche, Ecce homo. Translated by Mircea Ivănescu, Bucharest, Humanitas, 1996, pp. 28-29.

${ }^{9}$ Michel Foucault, "Practicarea plăcerilor" ["The Exercise of Pleasure"], in Istoria sexualității [The History of Sexuality]. Translated by Beatrice Stanciu, Timișoara, Editura de Vest, 1995, p. 193.

${ }^{10}$ Liviu Rebreanu and Panait Istrati are the other two writers who are members of the society's steering committee.

11 A comparison between the first two editions of this book (1939 and 1956) pours light on the changes that occurred in Romanian society after 1948. The second edition dwells more on the practical side of gastronomy. The fact is obvious mainly in the removal of chapters such as "Aranjarea menu-urilor" ["Designing the Menus"], "Arta serviciului" ["The Art of Table Waiting"] or "Politeța la masa" ["Table Manners"]. In addition, the first edition included menu suggestions, which were also removed in 1956 . The reason for these alterations is that they were seen by the new régime as a threat, a symbol of a world that the communists wanted forgotten. These practices were characteristic of the bourgeoisie, considered effete and, most importantly, obsolete, unconnected to
} 
de mâncare [The Gastronomic Dictatorship. 1501 Dishes]. Both these books were reissued after the Second World War and even after 1989. The most popular author of cookery books in Romania is Sanda Marin. The only purpose of mentioning her here is that of contrasting her with the authors that have been named so far. Her huge success was due to her book's practicality. The housewives were able to relate to her recipes, something that is not so easy as far as the recipes of Păstorel Teodoreanu go, for instance. The latter author embodies a certain noblesse, as his recipes hail from an old Romanian manorial heritage of French influence. This is also the case for Cartea de bucate boierești [Manorial Cookery Book] by Kogălniceanu and Negruzzi. The pedagogical purpose of this publication is obvious, the book being targeted at a rather aristocratic kind of reader.

Out of the inventory of factors that have influenced these intellectuals' affinity with gastronomy, the following can be listed: their upbringing, which presupposed the precocious cultivation of refined eating habits and the importance of the ceremonial aspect of a meal, and their personal predisposition to being gourmands, that is, to a certain type of dietetics ${ }^{12}$. These affinities transpire from the biographies of the authors mentioned so far. The cultivation of conviviality and togetherness was a natural attitude in the Teodoreanu household. The ceremonial atmosphere and good-humour were the main ingredients for such gatherings, according to both family members and guests. Demostene Botez, Pamfil Șeicaru, Al. A. Philippide were among the latter. Ștefana Velisar-Teodoreanu was deeply impressed by her future family at her first visit, as Moldavian hospitality was very intense. The same atmosphere appears to have impressed all those who had any contact with the Teodoreanu household. Even Al. O. Teodoreanu, who was rather reserved about giving personal testimonies, praised this idyllic climate. His words were aimed at criticising what he perceived as the degradation of the idea of home $^{13}$. To him, home represents on a small scale what Divanul meșterilor şi cărturarilor de la Hanul Ancuței represents on a larger scale: "fraternity is that which defines the community: after the fashion of family and love" 14 . So are most relationships between writers: based on the idea of fraternity.

Mihail Kogălniceanu is seen as a true gourmet not only due to the fact that he wrote a cookery book and that he was the first to translate into Romanian the 20 aphorisms that open Brillat-Savarin's book, but also due to his letters and his travel notes. As a student in France, he tries French comfiture which is something new in

the progress required of the new society. Unfortunately, the editions of 1995 and 1998 reproduce the 1956 edition.

${ }^{12}$ Michel Foucault, Practicarea plăcerilor, p. 186.

${ }^{13}$ Al. O. Teodoreanu, Tămâie și otravă [Incense and Poison], Timişoara, Editura de Vest, 1994, p. 189.

${ }^{14}$ Jean-Luc Nancy, Comunitatea absentă [The Absent Community]. Translated by Emilian Cioc, ClujNapoca, Idea Design\&Print, 2005, p. 33: "fraternitatea este cea care desemnează comunitatea: modelul familiei și al dragostei”. 
comparison with what he is used to back in Moldavia. As a result, he gets homesick and the only fact that cures his nostalgia is the remembrance of these tastes. Furthermore, his travel notes from Spain testify about his foreigner's interest in the country's variety of fruits and their origins ${ }^{15}$. The autobiographical element specific to Kogălniceanu's literary writings also comprises his gastronomic tastes. In Iluzii pierdute [Lost Illusions] the author declares himself aware of the novelty inherent in the publication of his and Negruzzi's foreign-inspired cookery book ${ }^{16}$. At the same time, the author of Scrisori la un prieten [Letters to a Friend] manifests his appetency for international cuisine and more diverse alimentation ${ }^{17}$. It does not mean that he excludes or ignores the Romanian - or, more specifically, Moldavian - tastes. On the contrary: for instance, he defends the authentic Moldavian pie, the kind unaltered by criticism about the assimilation of foreign trends ${ }^{18}$. The impact of Kogălniceanu and Negruzzi's book is similar to the revolutionary impact that Felix Barla and his confectioner's shop have on old Iași in Kogălniceanu's unfinished novel Tainele inimii [Secrets of the Heart].

Even if almost an entire century has passed since their creation, a pedagogical intent is still transparent in Al. O. Teodoreanu's gastronomic reviews. Păstorel is intransigent when it comes to following table manners. This unyielding position surfaces in the form of acid ironies and graphic verdicts that enthrall the reader. (Food) hygiene, table manners, manners in general (in public spaces or at home), the relations between the consumer and the service provider or those between the customer and the waiter/ bartender are pivotal aspects in the gastronomic Decalogue devised by Păstorel. Instead, a certain laxness is specific to the style and format of the recipes. Their authorship is constantly diverted to a third person as the reviewer prefers to set himself up as a simple mediator. Furthermore, the recipes are almost always scattered through with anecdotes. Thus, the recipes are either presented by a series of characters in the reviews (Costache, Yvonne and others) or displayed as part of a lost and found manuscript or as part of a dialogue that the reviewer has heard by chance, claiming that he does nothing but write them down. This strategy is specific to Al. O. Teodoreanu. He exploits it both in Hronicul măscăriciului Vălătuc [The Chronicle of Vălătuc the Jester] and in some texts from Tămâie și otravă [Incense and Poison].

The anecdotal pattern of Păstorel's reviews is another confirmation of the connection between culinary art and the art of storytelling. It is also a confirmation of the conviviality that is so characteristic for the meals of those who find

\footnotetext{
${ }^{15}$ Mihail Kogălniceanu, Scrisori. Note de călătorie [Letters. Travel Notes]. Edition by Augustin Z.N. Pop and Dan Simionescu, Bucharest, Editura pentru Literatură, 1967, pp. 225-226.

${ }_{16}$ Mihail Kogălniceanu, Tainele inimei. Scrieri literare şi istorice [Secrets of the Heart. Literary and Historical Writings]. Edition by Dan Simionescu, Bucharest, Albatros, 1987, p. 43.

17 Costache Negruzzi, Opere [Works]. Edition by Liviu Leonte, Bucharest, Academia Română, Fundația Națională pentru Știință și Artă, 2009, p. 259.

${ }^{18}$ Ibidem, p. 319.
} 
themselves in a state of "togetherness of thoughts and ideas". The fact is most obvious in Mihail Sadoveanu's fictional literature, in which two recurring motifs are frequently combined: that of literature (of storytelling) and that of gastronomy. Together they make up a scenario in which the ceremonial emerges even from the midst of simplicity (as in Crâșma lui moș Precu [Uncle Precu's Barrelhouse]. The importance of the ceremonial aspect is also obvious in another motif from the same series, namely hunting. As a result, the act of storytelling has mesmerizing effects on the world and on the listener, as one can see in Al. Odobescu's writings. The culinary scenario anticipates or succeeds hunting as a compulsory stage. For instance, in Sadoveanu's Cântecul de dragoste [The Love Song] the hunting preparations imply that plans for the hunters' meals are also to be made. This phase is recorded in the stories about the hunting expeditions organized by the members of Viața Românească. The most enthusiastic writers taking part in these expeditions were Mihail Sadoveanu and G. Topîrceanu, and the one so keen about the moment of the meal was M. Sevastos, who, not incidentally, was also the author of a cookery book ${ }^{19}$ himself. As ceremonial practices, both eating and hunting also have in common the idea of social gathering, of bringing people together, stipulating the distinctiveness of the hunter, as seen in Tara de dincolo de negură [The Land beyond Haze]. What dominates the pages of this kind of writing is the state of mind that Nicolae Steinhardt called in an essay "bunăvoință" ("geniality"). He found that writers like Odobescu, Sadoveanu, Brătescu-Voinești or the Teodoreanu brothers have this in common.

The recipes of the national cuisine were also translated as a form of keeping in touch with folk heritage and nationality. This is a process in which not every Western influence is rejected. The exploitation of the Romanian gastronomic art is a constant concern of the Divan. The group is founded on the idea of interrelation of the arts, intended to highlight the Romanian artists' potential and their creations against a European background. This is the kind of concern that Al. O. Teodoreanu, for instance, had in 1934 as pointed out in a letter to Al. Rosetti, the manager of Fundația pentru Literatură și Artă Carol II (The Carol II Foundation for Literature and Arts). The letter regards an exhibit organised by the European countries, which took place in Brussels. Păstorel views gastronomy as one of the arts that, if sensibly exploited, has all the advantages necessary for bringing about a most favourable view of Romania. Furthermore, he thinks that gastronomy can ensure a greater success than literature here, especially if combined with the proper mise en scène and with the proper traditional music ${ }^{20}$.

Both Al. O. Teodoreanu's gastronomic reviews and part of his fictional literature are written in praise of the Romanian cuisine and wines. The reviews

\footnotetext{
19 Mihail Sevastos, Amintiri de la „Viața Românească” [Memories from “Viața Românească”], Bucharest, Editura de Stat pentru Literatură şi Artă, 1956, p. 248.

${ }^{20}$ Rodica Pandele (ed.), Păstorel și corespondenții săi, p. 153.
} 
emphasize the fact that the specific qualities of the folk cuisine are a testimony to the degree of refinement of the national gastronomy. It is important to mention that folk cuisine in its highest form is most often instanced in the writings of Mihail Sadoveanu or in those of Calistrat Hogaș. Al. O. Teodoreanu illustrates instead a high-class sort of gastronomy, as his attitude is a rather aristocratic one. This fact does not rule out a certain recognition of the excellent attributes of folk cuisine and Păstorel exemplifies this in his story Pursângele Căpitanului [The Captain's Thoroughbred]. The text is part of Hronicul măscăriciului Vălătuc, in which History is left behind so that history can showcase an alternative past. Thus, the reader finds out more from this story than it is obvious at first sight. Al. O. Teodoreanu succeeds in framing "a personal version of national identity and, at the same time, a discourse about the best way this identity could be refreshed and celebrated" 21 by means of a story in which national cuisine, Western culinary adaptations, the Zippas' wines and their twisted love life are featured. Doris Mironescu points out that the events that Teodoreanu has chosen to write about are representative of what Maurice Halbwachs referred to as "collective memory", which has been preferred by Teodoreanu to that provided by history. All this in order to outline "an image of the past from a community's perspective" 22 . The pedagogical intentions of Păstorel's gastronomic reviews are defended in the story by the boyar Toader Zippa.

On the other hand, for Mihail Sadoveanu folk gastronomy as part of a national cuisine is an iterative aspect. What matters in his writings is not the content or the abundance of a meal, but the ceremonial implied by it. It must be noted in this respect that the repasts in Sadoveanu's stories are not heavy on sophisticated courses. The main interest lies in the same idea of bringing together the people of a community and in the atmosphere that these people are able to create by means of their stories. For instance, the new Ancuța charms the customers at her inn both with the dishes she serves and with the ambience created around the tables. The same holds true for Calistrat Hogaș. In his writings, simplicity culminates, reaching a degree $\grave{a}$ la Rousseau, considered equal to perfection. The importance of the meal is augmented by the journey through the wild and by the presence of a companion. The recurrent reluctance and complaints of this companion are counterpoised by the geniality of the protagonist. As a matter of fact, Hogaș was described by his coevals as a gourmet for whom a morsel and a glass of red wine were of great importance. Those two key ingredients are indicative of a kind of sanguine

\footnotetext{
${ }^{21}$ Doris Mironescu, "Păstorel. Sentimentul apartenenței la vinuri și popoare” ["Păstorel. The Feeling of Affiliation to Wines and Nationalities"], in Un secol al memoriei. Literatură și conștiință comunitară în epoca romantică [A Century of Memory. Literature and Community Consciousness in the Romantic Era], Iași, Editura Universității „Al. I. Cuza”, 2016, p. 180: “o versiune personală a identității naționale și totodată un discurs despre modul în care această identitate poate fi cel mai bine rememorată și celebrată".

22 Ibidem, p. 179: "reprezentare a trecutului mediată de comunitate".
} 
mythology 23 , representing an alternative return to nature. Hogaș's daughter considered such descriptions of her father false. By having his affinities qualified as savage, her perspective shows a bias indicating some degree of priggishness. Moreover, her desire is to separate such practices from her father's image. Instead, she makes a hagiographic portrait of him as she criticises his presumed detractors ${ }^{24}$.

Fascinating facts can also emerge from analyzing the relation between gastronomy and time, as the former operates and depends on the latter. This relation is based on the ephemeral quality of the objects in question. Under these conditions, the cook is an artist whose creation is not destined to last. Thus, he is as "a Sisyphus, sentenced to perform again and again something forever doomed to evanescence." 25 Even though it is a phenomenon of the present moment, culinary creation embodies in its peculiarity and short existence the entire essence of the universe, beginning with the genesis and ending with death. It is its ephemeral nature that has made gastronomy an interesting art for modernity. In times such as ours, while praising speed and the present moment, it is natural that gastronomy should gain our attention. As meals are reiterative moments of the day-to-day life, the perception of a dish also stimulates the remembrance of a similar previous experience. Savour and its perception are able to induce more or less unusual associations and lasting sensations which will become a reference standard for all subsequent gastronomic experiences. Moreover, the taste of a meal can also be a reference point for other experiences, as exemplified by Proust's madeleine. The entire configuration of such a moment can be re-visualized or symbolically reenacted in the subject's mind whenever he is exposed to stimuli that allow such a complex form of remembrance. The present duplicated as perception is simultaneously accompanied by memory. Thus, the culinary scenario itself becomes dual, as "two different selves are created, one becoming a spectator and the other a performance with a plot known in advance" 26 . The process described is an unusual mise en abyme which augments the ceremonial aspect of the gastronomic scenario. The impermanence of gastronomic art is, however, another reason for a punster such as Al. O. Teodoreanu to be drawn to it. Both his literature and his life betray his instinctive fondness of temporariness and immanence. Hence his appetency for the secondary, for small forms both in art and life, is discernible both in his epigrams and in his bohemian lifestyle.

\footnotetext{
${ }^{23}$ Roland Barthes, Mitologii, p. 94.

${ }^{24}$ Sidonia C. Hogaș, Tataia. Amintiri din viața lui Calistrat Hogaș [Tataia. Memories from Calistrat Hogaș's Life], Piatra-Neamț, Crigarux, 2000, pp. 44-45.

${ }^{25}$ Michel Onfray, Rațiunea gurmandă, p. 113: “[este asemeni] unui Sisif condamnat să facă și să refacă ceea ce este neîncetat sortit dispariției”.

${ }^{26}$ Remo Bodei, Senzația de déjà vu [The Déjà Vu Sensation]. Translated by Alex. Cistelecan, Bucharest, Art, 2009, p. 95: "iau naștere două euri diferite, dintre care unul se transformă în spectator, iar celălalt, în spectacol cu o intrigă dinainte cunoscută”.
} 
A meal and its cultural implications activate an entire semiotic system. Moreover, a meal itself becomes a symbol - of a person, of a community, of a cultural space, of a certain civilization, of a certain time; a symbol that bears testimony of the process of civilization, whose main agents and witnesses are artists. As a secondary phenomenon, meals illustrate on a small scale the social progress of the mainstream. They can also be a way of knowledge and selfknowledge. Gastronomy exploits all the senses through a form of aesthetics of life initiated by the individual in order to gain access to the universal. Meals are based on a scenario where two of the main assets are conviviality and the feeling of affiliation to a community. Based on these criteria, writers and artists are committed to gastronomy regarded as an art asserting a certain type of sensibility and reverberating in their creations. Furthermore, through the celebration of the senses, this form of art cultivates the communion of all arts and of those who practise them.

\section{BIBLIOGRAPHY}

AGAMBEN, Giorgio, "Prietenul" ["The Friend"], in Prietenul și alte eseuri [The Friend and Other Essays]. Translated by Vlad Russo, Bucharest, Humanitas, 2012, pp. 5-21.

BACALBAȘA, Constantin, Dictatura gastronomică. 1501 feluri de mâncare [The Gastronomical Dictatorship. 1501 Dishes]. Edition by Simona Lazăr, Bucharest, Cartex, 2009.

BARTHES, Roland, Mitologii [Mythologies]. Translated by Maria Carpov, Bucharest, Vellant, 2015.

BODEI, Remo. Senzația de déjà vu [The Déjà Vu Sensation]. Translated by Alex. Cistelecan, Bucharest, Art, 2009.

BRILLAT-SAVARIN, Jean-Anthelme, Fiziologia gustului [The Physiology of Taste]. Translated by Adriana Lăzărescu, Bucharest, BCC Publishing, 2015.

FOUCAULT, Michel, "Practicarea plăcerilor" ["The Use of Pleasure"], in Istoria sexualității [History of Sexuality]. Translated by Beatrice Stanciu, Timişoara, Editura de Vest, 1995, pp. 1-3.

GHERAN, Niculae, "Divanul meșterilor și cărturarilor de la Hanul Ancuței" ["The Masters and Scholars' Divan of Ancuța's Inn”], Adevărul literar și artistic, 2003, 665, p. 13.

HOGAȘ, Calistrat, Opere I [Works I]. Edition by Daciana Vlădoiu, Bucharest, Minerva, 1984.

HOGAȘ, Sidonia C, Tataia. Amintiri din viața lui Calistrat Hogaș [Tataia. Memories from the Life of Calistrat Hogaș], Piatra-Neamț, Crigarux, 2000.

KOGĂLNICEANU, Mihail, and NEGRUZZI, Costache, Carte de bucate boierești. 200 rețete cercate de bucate, prăjituri și alte trebi gospodărești [Manorial cookery book. 200 practiced recipes of edibles, cakes and other domesticities]. Edition by Mircea Zaciu, Cluj-Napoca, Dacia, 1973; Ediție îngrijită de Rodica Pandele, Bucharest, Vremea, 2007.

KOGĂLNICEANU, Mihail, Tainele inimei. Scrieri literare și istorice [The Secrets of the Heart. Literary and Historic Writings]. Edition by Dan Simionescu, Bucharest, Albatros, 1987.

KOGĂLNICEANU, Mihail. Scrisori. 1834-1849 [Letters. 1834-1849]. Preface by Petre V. Haneș, Bucharest, Minerva, 1913.

KOGĂLNICEANU, Mihail. Scrisori. Note de călătorie. [Letters. Travel Notes]. Edition by Augustin Z.N. Pop and Dan Simionescu, Bucharest, Editura pentru Literatură, 1967.

KRIZSANOVSZKI, Izabella, Fascinația enogastronomică în literatura română [Eno-gastronomic Fascination in Romanian Literature], Iași, Tipo Moldova, 2010.

MARIN, Sanda, Carte de bucate [Cookery Book], Bucharest, Cartea Românească, 1945. 
MIRONESCU, Doris, "Păstorel. Sentimentul apartenenței la vinuri și popoare" ["Păstorel. The Feeling of Affiliation to Wines and Nationalities"], in Un secol al memoriei. Literatură și conștiință comunitară în epoca romantică [A Century of Memory. Literature and Consciousness of Community in the Romantic Era], Iași, Editura Universității „Al. I. Cuza”, 2016, pp. 169-184.

NANCY, Jean-Luc, Comunitatea absentă [The Inoperative Community], Translated by Emilian Cioc, Cluj-Napoca, Idea Design\&Print, 2005.

NEGRUZZI, Costache, Opere [Works]. Edition by Liviu Leonte, Bucharest, Academia Română, Fundația Națională pentru Știință și Artă, 2009.

NIETZSCHE, Friedrich, Ecce homo, Translated by Mircea Ivănescu, Bucharest, Humanitas, 1996.

ONFRAY, Michel. Rațiunea gurmandă. Filozofia gustului [Gourmet Mind. The Philosophy of Taste]. Translated by Claudia Dumitriu and Lidia Simion, Bucharest, Nemira, 2000.

PANDElE, Rodica (ed.), Păstorel și corespondenții săi [Păstorel and His Correspondents], Bucharest, Eminescu, 1998.

SADOVEANU, Mihail, Opere 1 [Works I], Bucharest, Editura de Stat pentru Literatură și Artă, 1954.

SADOVEANU, Mihail, Opere 10 [Works X], Bucharest, Editura de Stat pentru Literatură și Artă, 1957.

SADOVEANU, Mihail, Opere 8 [Works VIII], Bucharest, Editura de Stat pentru Literatură și Artă, 1957.

SEVASTOS, Mihail, Amintiri de la „Viața Românească” [Memories from “Viața Românească”], Bucharest, Editura de Stat pentru Literatură și Artă, 1956.

SEVASTOS, Mihail, Carte de bucate [Cookery Book], Bucharest, Cugetarea, 1939; Bucharest, Editura Tehnică, 1956; Bucharest, Vox, 1998.

STEINHARDT, Nicolae, "Ioan Al. Brătescu-Voinești, 'Călătorului îi șade bine cu drumul"” ["Ioan Al. Brătescu-Voinești, 'The Traveler Beseems with the Road"'], in Prin alții spre sine. Eseuri vechi și noi [Through Others towards Yourself. Old and New Essays], Bucharest, Eminescu, 1988, pp. 145-148.

TEODOREANU, Al. O. De re culinaria. Edition by Rodica Abrudan Palade and Aristița Avramescu, Bucharest, Sport-Turism, 1977.

TEODOREANU, Al. O. Gastronomice [Gastronomicals]. Edition by Grigore Damirescu and Valentin Borda, Bucharest, Editura pentru Turism, 1973.

TEOdOREAnU, Al. O., Hronicul măscăriciului Vălătuc. Proză umoristică [The Chronicle of Vălătuc the Jester. Humoristic Prose]. Postface by Gh. Hrimiuc, Iași, Junimea, 1989.

TEODOREANU, Al. O., Tămâie și otravă [Incense and Poison]. Edition by Alexandru Ruja, Timişoara, Editura de Vest, 1994.

VELISAR-TEODOREANU, Ștefana, Ursitul [The Soulmate], Bucharest, Minerva, 1979.

\section{THE PHYSIOLOGY OF TASTE. FROM CULINARY TO LITERARY ART (Abstract)}

The purpose of this paper is to look at gastronomy as a form of art. In this respect, gastronomy developed as part of the civilizing process and as the refinement of the mores progressed. Just as literature, gastronomy implies the ideas of pleasure and experiment. As writers displayed a great interest in gastronomy, this form of art also became a subject of their literature and, at a more subtle level it became an exercise in a certain sensibility. The present study proposes an insight into literary history in its gastronomic implications in the writings of Romanian authors such as M. Kogălniceanu, C. Negruzzi, M. Sadoveanu or Al. O. Teodoreanu. They displayed a conspicuous interest in culinary art, in the physiology of taste as well as in modernity's innovations. 
Keywords: modernity, savour, gastronomy, refinement, experiment, cookery books, literature, biography.

\section{FIZIOLOGIA GUSTULUI. \\ DE LA ARTA CULINARĂ LA ARTA LITERARĂ \\ (Rezumat)}

Scopul acestei lucrări este să abordeze gastronomia ca o formă de artă. Rezultat al evoluției civilizației și al rafinării moravurilor, gastronomia implică - la fel ca literatura - plăcerea și experimentul. Fiindcă scriitorii au manifestat un interes major față de gastronomie, această formă de artă a devenit nu doar un subiect al literaturii, ci și un mod de exercitare a unei sensibilități aparte. Acest articol propune o cercetare de istorie literară dedicată implicațiilor gastronomiei în scrierile unor autori precum M. Kogălniceanu, C. Negruzzi, M. Sadoveanu sau Al. O. Teodoreanu, de vreme ce toți au dovedit un interes vădit pentru arta culinară, pentru fiziologia gustului, precum și pentru inovațiile modernității.

Cuvinte-cheie: modernitate, savoare, gastronomie, rafinament, experiment, cărți de bucate, literatură, biografie. 